\title{
Expert System for Predicting Children Mental Retardation using Forward Chaining
}

\author{
Riyan Naufal Hays ${ }^{1}$, Akip Suhendar ${ }^{2}$, Ila Amaliah ${ }^{3}$, Sumiati $^{4}$, Zaenal Muttain ${ }^{5}$, Dian \\ Sa'adillah Maylawati ${ }^{6}$ \\ \{riyan.unsera@gmail.com¹, akip.suhendar@gmail.com², ilaamalia.id@gmail.com³, \\ sumati82@yahoo.com ${ }^{4}$, d.zaey.vu@gmail.com ${ }^{5}$, diansm@uinsgd.ac.id ${ }^{6}$ \} \\ Department of Informatics, Universitas Serang Raya, Indonesia ${ }^{1,2,3,4,5}$ \\ Department of Informatics, UIN Sunan Gunung Djati Bandung, Indonesia ${ }^{6}$ \\ Faculty of Information and Communication Technology, Universiti Teknikal Malaysia Melaka, \\ Malaysia $^{6}$
}

\begin{abstract}
Mental retardation is also known as intellectual disability. The symptoms of mental retardation can be detected early since children. This research aims to develop an Expert System (ES) to predict mental retardation in children with 4 type of mental retardation, among others: mild, moderate, severe, and very severe. This ES which is contained the expert knowledge is developed using Forward Chaining (FC) algorithm as research method. Besides to detect type of mental retardation, this ES provides the treatment information based on the type of mental retardation that suffered. Black box testing result that showed all of system functionalities run well, the results of the questionnaire on the ease of use of the system with some respondents also showed good results. Besides, based on the experiment with 23 of symtomps, 4 main rules, and 20 additional rules, showed that FC caplable to predict the mental retardation in children well enough.
\end{abstract}

Keywords: Expert System, Forward Chaining, Mental Retardation

\section{Introduction}

Children is the best gift given by God towards human and the hope for the parents as the successor of the decendant and hoped that the children will be successfull in the future. There are some children who born in a perfect normal condition, however, there are also children who were born with physical or psychological limitation. A child who has the physical and mental retardation can disturb the development and the growth unnormally [1]. Children who are included in the category of special needs or can be said disabled children, are children with mental retardation where the children needs special treatment. Mental retardation known with the term intelectual disability, mental deficit, mental subnormality or mental handicap (the slow growth of the mental development), that is the imbalance of intelectual process that cause individual hard to face the environment where he or she is [2]. The low number of cognitive function, emotional and social suffered by children who had mental retardation caused difficulty for children to oricess information [1].

Based on Te ICD-10 Classification Of Mentaland Behavoural Disorders, WHO, Geneva 1994 mental retardation was divided into 4 categories; they are light mental retardation (with 
Intelligence Quotient (IQ) between 50 and 69), mild mental retardation (with IQ between 35 and 49), heavy mental retardation (with IQ between 20 and 34), and very heavy mental retardation (with IQ less than 20). Parents who know that the children had special needs may have confusion in how to take care of and care for the special needs children, moreover the parents who have no understanding about the categories of mental retardation suffered by the children. This situation that push the scientist to develop a technology which is able to develop the use of computer like human, this thing can be created by applying one of manufactured intelegencial science by making expert system that consist of information about children mental retardation inside and build expert system in taking the decision that will help in predicting the type of the level category of mental retardation children [3].

However, from the total population of Indonesia in 2010 according to the Central Statstic Agency in Indonesia, from 238.5 million if it was assumed that the incidence of mental retardation in Indonesia was approximately $3 \%$ of the population, so the estimated number of mental retardation sufferers was 7.15 million [4], [5]. For this reason, parents play an important role in educating children, providing good training in mentally retarded children who are likely to improve children's thinking and ways of knowing their strengths and weaknesses so they can be confident in making decisions.

Today, in Industrial 4.0 era, Artificial Intelligent (AI) is utilized rapidly in many sector and various case study [6], [7], either in economic [8], medicine [9], education [10], [11], game [12], [13], health [14]-[16], and so on. AI technology make computer more intelligent so that can solve various and complex problem. One of AI tehnology that widely used is Expert System (ES). ES is a system that makes computers learn intelligently with expert knowledge inside to solve problem with prediction and also recommendation [3], [17]. ES is not used to replace an expert, but to help and expert, as well as a bridge between users other than experts and experts to get solutions for their problem easy [18]. In previous research, many method that used in ES research, such as Fuzzy algorithm [19], Backward Chaining [20], and also one of the widely used is Forward Chaining (FC) [21]-[23].

FC method is suitable to be used to handle controlling, prognosis problems, and the rules have been clearly defined [24]. There are several related works in ES that used to diagnose mental disorders with FC and the result is quite good [19], [25], [26]. Therefore, in this ES research implement the FC method to diagnose kinds of mental retardation based on the symptoms experienced by the children in daily life. This ES can make the society especially parents easy in diagnosing the mental retardation and knowing how to handle through the informations given. Beside that, parents who have difficulties in finding expert to consult about mental retardation suffered by the children can interact through the system without have to worry about time and distance.

\section{Methodology}

This research used Waterfall as Software Development Life Cycle (SDLC) as methodology to build an ES application. Waterfall is used because it is the simple one of SDLC and the requirements of the system have clearly and completely defined [27], [28]. Furthermore, Waterfall is suitable for the rigid and critical system such as ES that used to predict health. Mean while, to predict the kinds of mental retardation is used FC algorithm based on several disesase. 


\subsection{Waterfall Software Development Life Cycle}

There are several main phase in Waterfall SDLC to build ES for predicting children mental retardation using FC algorithm that describe in Figure 1, among others [28]: requirement elicitation, analysis, design, implementation, testing, deployment/operation, and maintenance. But, in this research is not conduct the deployment/operation and maintenance phase. In every phase is conduted based on the ES needs, among others:

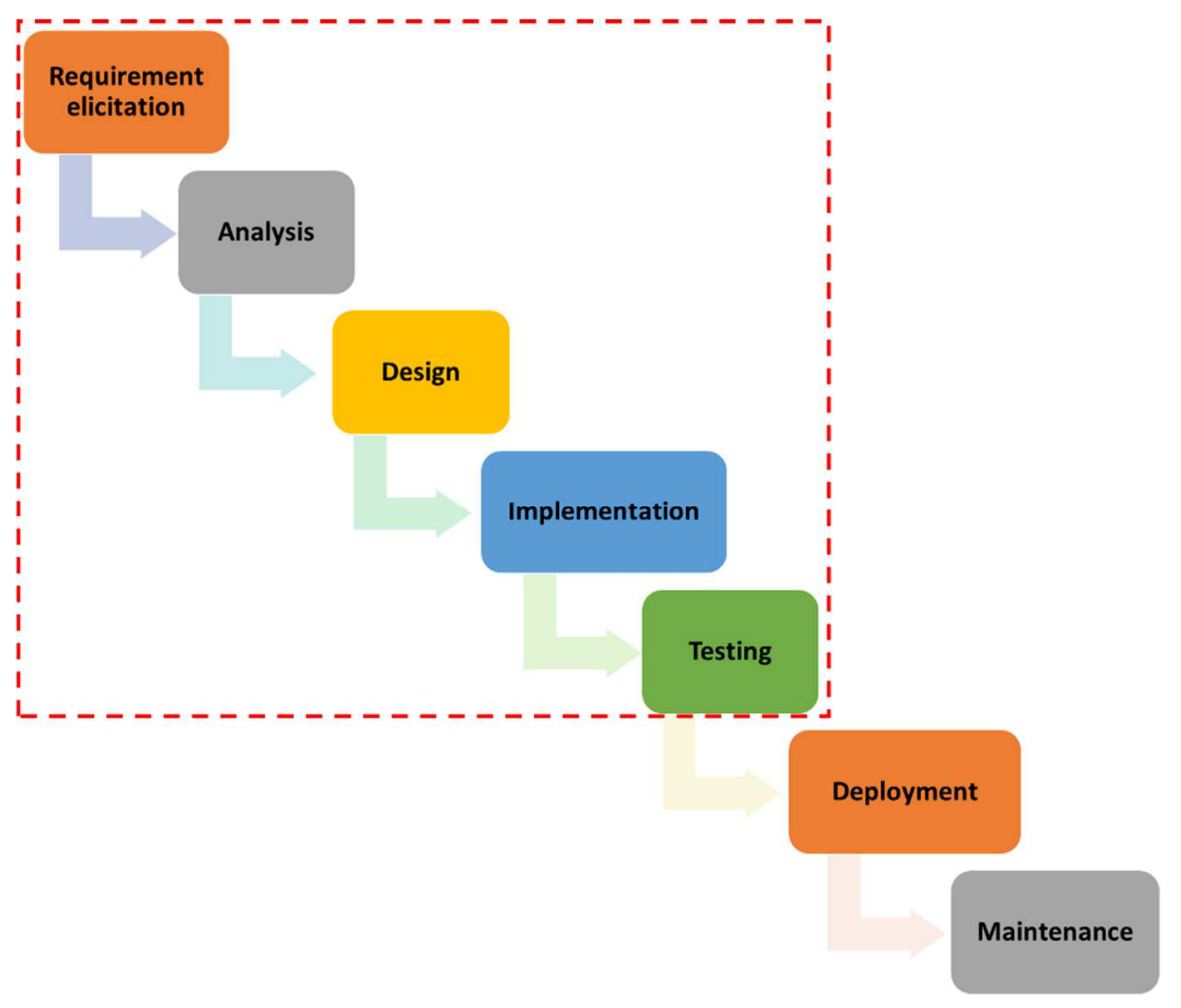

Fig. 1 Waterfall SDLC [28]

\section{Requirement Elicitation}

Requirement elicitation is an important phase to collect the information completely [29]. Requirement about mental retardation is elicitated with direct observation in AlKautsar School with Special Needs. Besides observing the condition happened with children with mental retardation, it is also interview the interviewee or expert in the mental retardation about the disease, treatment, and also recommendation. All of the information is collected to be analyze as an ES needs.

\section{Analysis}

In this phase, all of information from requirement elicitation are analized in accordance with the ES needs. Because not of all the information from stakeholders must be available in the system directly. In the analysis phase, the ES functional and non 
functional requirement are defined. All of the symptoms and the rules to predict mental retardation is also analyzed and modeled as rule-based model and decision tree.

\section{Design}

Functional and non-functional of the system is elaborated to be more detail in the design phase. The design phase represent the existing system to be ES that can make the user (either the patient, the expert, or citizen) easier in the using and applying process of ES to diagnose or predict the mental retirdation in children. In this phase also design the prototype or user interface of the system

\section{Implementation}

In the implementation phase, the ES is coded using PHP programming language with web-based platform. With web-based application, the user easier in using an ES by visiting the web site, because can access in the desktop or mobile. FC algorithm will be implemented in this phase and make the ES run based on the rules that represent an expert knowledge inside

\section{Testing}

Testing phase is conducted with two types, among others black box testing that used for test the funtionality of the system and expert judgment evaluate to maesure that the system correct and reliable to predict the children mental retardation. In this phase can be shown the performance and usability of the system that measured by qestionnaire. An also, testing phase that is directly tested by the interviewee or expert can evaluate what are the mistakes that should be fixed early so that the application become better and comfortable to be used.

\subsection{Forward Chaining Method}

FC method is a searching system or tracing technique that started with the existed information and combine the rule to create a conclusion or the purpose [6]. FC is very good if it is work with the problem started with the first record of information and want to reach the end of solving, because the whole process will be done in forward order. FC is a rule-based algorithm that represent the facts using IF-THEN-ELSE form [24], [30], then prove the valid argument using modus ponens and Breadth First Search, Depth First Search, or Best First Search to solve the problem that represent with decision tree [31], [32].

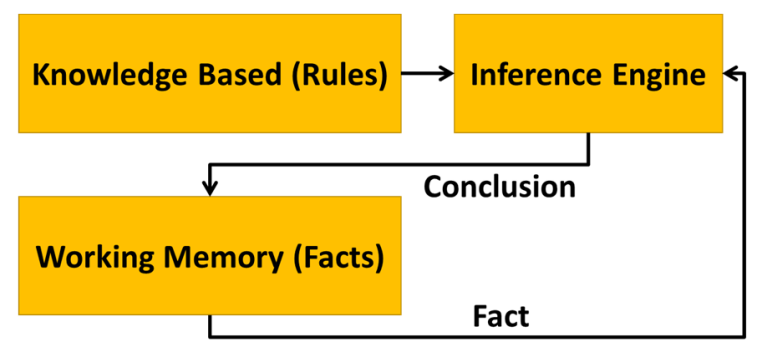

Fig. 2 Forward Chaining Rule-based Model [23], [26] 
From Figure 2, the rules that representing knowledge (if in ES it means expert knowledge) will be processed in inference engine and produced the conclusion. The process between inference engine and working memory is repeated based on whether the solution has been found or not yet. FC search a rules or facts that related with the problem to find the solution or conclusion. The conclusion will be produced if the premise clause matches with the problem. FC methos is simple in accordane with the needs of rules that have been available. The proess of FC begin from input the problem (new facts) into system, then if that new facts matched in the IF section, then the rules will be executed and produce the solution. However, it the new facts is not matched with the IF condition, then it will be check the next rules in the ELSE section.

\section{Results and Discussions}

This section shown the result of the research and several discussion following the Waterfall SDLC phases which is methodology of this research. Begin from requirement elicitation phase, analysis, design, implementation, until test the ES for predicting children mental retardation.

\subsection{Requirement Elicitation Result}

Based on observation in Al-Kautsar School of Special Needs, from the result of the IQ test examination can diagnose the mental of children, especially if they have possibility of experiencing one of the type of mental retardation. The psychologists will inform the parents and the teacher to conduct a direct observation process with the mentally retarded child, observes the child's behavior and what symptoms are seen and looks at the history of the child's previous illness recorded then concluded. After that it is put into a classroom specifically for persons with mental retardation for the learning stage. However, the suitable predition, what treatment and suggestion of what type of mental retardation that experienced by the child is not clearly defined. There must be a follow-up check on the expert. So that this ES for predicting children mental retardation is important to build.

From the previous research that related with mental retardation in school-age children [33]-[36], there are 4 types of children mental retardation, among others: mild mental retardation, moderate mental retardation, severe mental retardation, and very severe mental retardation. The characteristics of each type are desribe in Table 1. Table 1 also describes the desrcription, symptoms, and the treatment of each type of children mental retardation.

Table. 1 Type of Children Mental Retardation

\begin{tabular}{|c|c|c|c|}
\hline Type & Description & Symptoms & Treatment \\
\hline Mild & $\begin{array}{l}\text { This level, a } \\
\text { children have an } \\
\text { IQ range from } \\
50-55 \text { to } 70 \text {, in } \\
\text { this case it is still } \\
\text { easy to carry out } \\
\text { daily activities. }\end{array}$ & $\begin{array}{l}\text { 1. } \begin{array}{l}\text { Being able to communicate } \\
\text { properly }\end{array} \\
\text { 2. Can still be trained and } \\
\text { educated } \\
\text { 3. Having a normal face character } \\
\text { like an ordinary child }\end{array}$ & $\begin{array}{l}\text { It is recommended that if } \\
\text { you do not enter school, } \\
\text { you are expected to enter } \\
\text { a special school, in daily } \\
\text { activities at home, you are } \\
\text { taught how to take care of } \\
\text { your home and take care } \\
\text { of yourself continuously, }\end{array}$ \\
\hline
\end{tabular}




\begin{tabular}{|c|c|c|c|}
\hline Type & Description & Symptoms & Treatment \\
\hline & & $\begin{array}{l}\text { 4. Can be trained to develop } \\
\text { abilities simply in good } \\
\text { condition } \\
\text { 5. Able to take care of themselves } \\
\text { independently } \\
\text { 6. Smooth talking but difficulty in } \\
\text { the language treasury } \\
\text { 7. Attention is easily diverted } \\
\text { 8. Can return the message that has } \\
\text { been given to the child }\end{array}$ & $\begin{array}{l}\text { then identify the potential } \\
\text { of children in the field of } \\
\text { expertise and teach them } \\
\text { to be self-employed or do } \\
\text { small business. }\end{array}$ \\
\hline Moderate & $\begin{array}{l}\text { At this level } \\
\text { children take part } \\
\text { in simple social } \\
\text { activities that } \\
\text { have a range of } \\
\text { IQ } 35 \text { until } 49 .\end{array}$ & $\begin{array}{l}\text { 1. Being able to communicate } \\
\text { properly } \\
\text { 2. Can still be trained and } \\
\text { educated } \\
\text { 3. Experiencing delays in the } \\
\text { development of language } \\
\text { understanding and use } \\
\text { 4. Limited ability in school } \\
\text { 5. Difficulty in returning the } \\
\text { message that has been given } \\
\text { 6. Have a parroting habit } \\
\text { 7. Limited language development } \\
\text { 8. Has a childish nature } \\
\text { 9. Have a daydreaming habit } \\
\text { 10. Abstract thinking difficulties } \\
\text { namely reasoning skills and } \\
\text { thinking well }\end{array}$ & $\begin{array}{l}\text { It is recommended that if } \\
\text { you have not entered } \\
\text { school, you are expected } \\
\text { to enter a special school, } \\
\text { in daily activities at home } \\
\text { you are taught how to } \\
\text { take care of your home } \\
\text { and take care of } \\
\text { themselves continuously } \\
\text { and periodically, get } \\
\text { closer to children and } \\
\text { more often invite children } \\
\text { to communicate in order } \\
\text { to communicate fluently } \\
\text { and speak well }\end{array}$ \\
\hline Severe & $\begin{array}{l}\text { At this level a } \\
\text { children have a } \\
\text { motor disorder, } \\
\text { abnormal } \\
\text { development of } \\
\text { the central } \\
\text { nervous system } \\
\text { that is severe and } \\
\text { has an IQ range } \\
\text { of } 20 \text { until } 34\end{array}$ & $\begin{array}{l}\text { 1. When speaking the words } \\
\text { spoken are simple } \\
\text { 2. Not able to distinguish danger } \\
\text { 3. Can be trained to take care of } \\
\text { himself slowly } \\
\text { 4. Can still be trained but cannot } \\
\text { be educated }\end{array}$ & $\begin{array}{l}\text { Give extra attention to } \\
\text { children, train children in } \\
\text { carrying out their own } \\
\text { activities even though } \\
\text { only very small activities } \\
\text { are continuously taught } \\
\text { with patience }\end{array}$ \\
\hline Very Severe & $\begin{array}{l}\text { At this level a } \\
\text { person is difficult } \\
\text { even unable to } \\
\text { understand or } \\
\text { obey requests or } \\
\text { instructions, } \\
\text { requires constant } \\
\text { help and } \\
\text { supervision and } \\
\text { has an IQ of less } \\
\text { than } 20\end{array}$ & $\begin{array}{l}\text { 1. When speaking the words are } \\
\text { simple } \\
\text { 2. Not able to distinguish danger } \\
\text { 3. Limited ability to understand } \\
\text { and comply with requests or } \\
\text { instructions } \\
\text { 4. Not able to maintain themselves }\end{array}$ & $\begin{array}{l}\text { Give extra attention to the } \\
\text { child, always under } \\
\text { supervision, try to train } \\
\text { the child to follow } \\
\text { instructions even though a } \\
\text { small possibility can be } \\
\text { applied. }\end{array}$ \\
\hline
\end{tabular}




\subsection{Analysis Result}

From the requirement elicitation result, the conclusion or the output of ES is Mild Mental Retardation, Moderate Mental Retardation, Severe Mental Retardation, and Very Severe Mental Retardation (available in Table 2). Those conclusion are resulted from 23 symptoms that are analized from Table 1. Table 3 desscribes the symptoms and code of each symptoms. The functional requirements of the ES is modeled using Use Case Diagram that describe in Figure 3. While, for the non-functional requirements, this ES must be reach functionality, correctness, and accuracy factor of software quality. It means that all of the functionality of system must be run well, with correct all of the logic, and has good accuracy to predict children mental retardation.

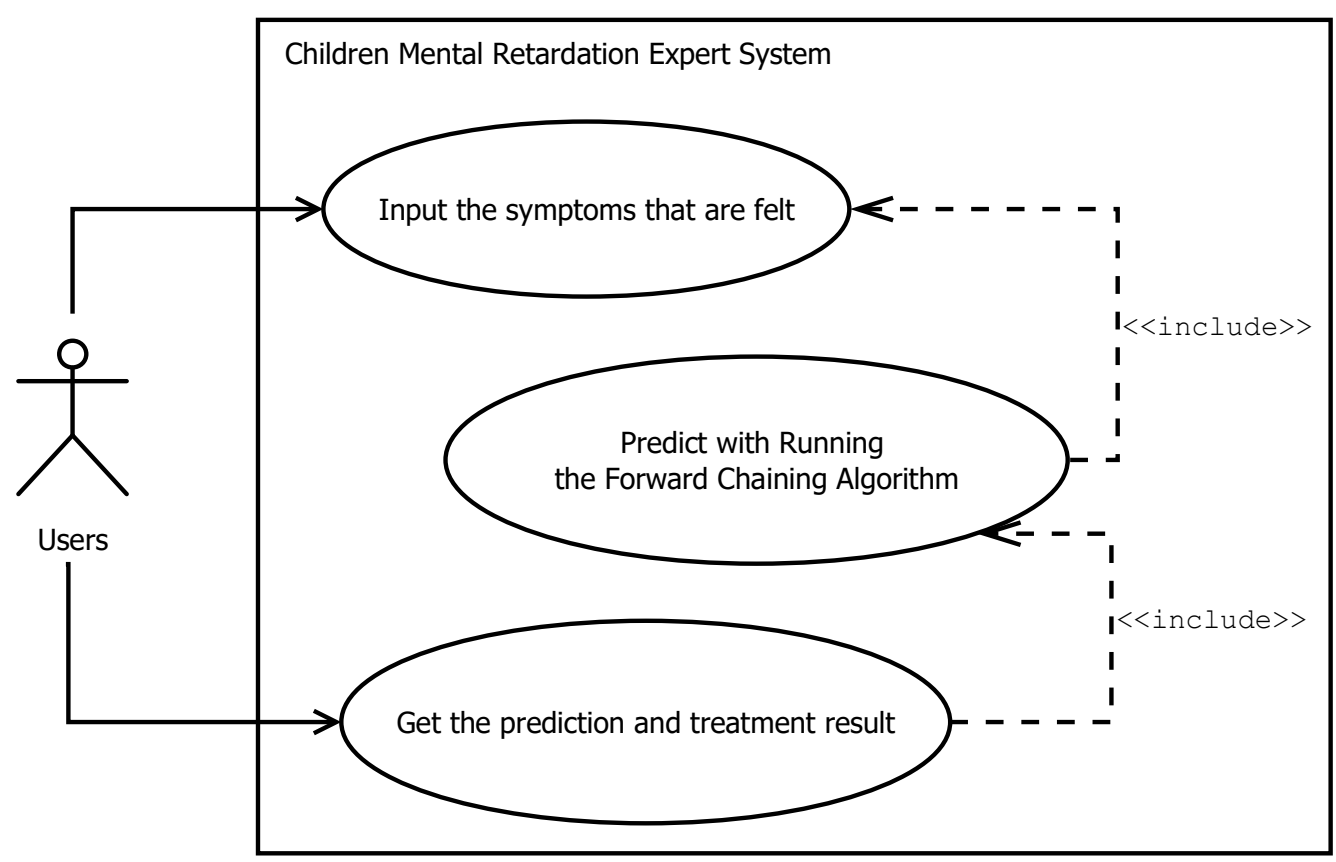

Fig. 3 Use Case Diagram for Children Mental Retardation Expert System

Table. 2 Code of Children Mental Retardation Types

\begin{tabular}{ll}
\hline Code of Mental Retardation Types & Name of Mental Retardation Types \\
\hline P001 & Mild Mental Retardation \\
P002 & Moderate Mental Retardation \\
P003 & Severe Mental Retardation \\
P004 & Very Severe Mental Retardation \\
\hline
\end{tabular}


Table. 3 Code of Children Mental Retardation Symptoms

\begin{tabular}{ll}
\hline Symptomps Code & Symptoms Description \\
\hline G001 & Can be invited to communicate well \\
G002 & Can be trained and educated \\
G003 & Have a normal face character like an ordinary child \\
G004 & Can develop abilities simply in good condition \\
G005 & Able to take care of themselves independently \\
G006 & Fluent speaking but difficulty in language vocabulary \\
G007 & Attention is easily transferable \\
G008 & Can return the message that has been given to the child \\
G009 & Experiencing delays in language development and understanding \\
G010 & School ability is limited \\
G011 & Difficulty in returning a message that has been given \\
G012 & Have a parroting habit \\
G013 & Limited language development \\
G014 & Childish \\
G015 & Have a daydreaming habit \\
G016 & Difficulty in thinking abstractly in reasoning skills and thinking well \\
G017 & Still able to distinguish danger and not danger \\
G018 & When speaking the words are simple \\
G019 & Not able to distinguish danger \\
G020 & Can be trained to take care of himself slowly \\
G021 & Can still be trained but cannot be educated \\
G022 & Limited ability to understand and comply with requests or instructions \\
G023 & Unable to maintain themselves \\
\hline
\end{tabular}

The output prediction from Table 2 and the symptoms from Table 3 are represented with IF-THEN form as rule-based representation. Then, the rules will be represented with decision tree so that the system will be saved the knowledge in the tree data structure. The rules of children mental retardation symptoms are available in Table 4 as matrix mapping, Table 4 as rule-based representation, and Figure 4 as tree structure that use binary tree data structure. Decision tree diagram will make it easier to arrange the basic knowledge and the rule and deciding the conclusion of the kinds of mental retardation from every identification action and some symptoms. For the node or rule do not included in the four types of mental retardation, it can be said that they did not experience the mental retardition or unpredictable.

Table. 4 Relation Matrix between Symptoms and Mental Retardation Types

\begin{tabular}{|c|c|c|c|c|}
\hline \multirow{2}{*}{ Symptom Code } & \multicolumn{4}{|c|}{ Code of Mental Retardation Types } \\
\hline & P001 & $\mathrm{P} 002$ & $\mathrm{P} 003$ & P004 \\
\hline G001 & $\mathrm{x}$ & $\mathrm{x}$ & & \\
\hline G002 & $\mathrm{x}$ & $\mathrm{x}$ & & \\
\hline G003 & $\mathrm{x}$ & & & \\
\hline G004 & $\mathrm{x}$ & & & \\
\hline G005 & $\mathrm{x}$ & & & \\
\hline G006 & $\mathrm{x}$ & & & \\
\hline G007 & $\mathrm{x}$ & & & \\
\hline G008 & $\mathrm{x}$ & & & \\
\hline G009 & & $\mathrm{x}$ & & \\
\hline G010 & & $\mathrm{x}$ & & \\
\hline G011 & & $\mathrm{x}$ & & \\
\hline
\end{tabular}




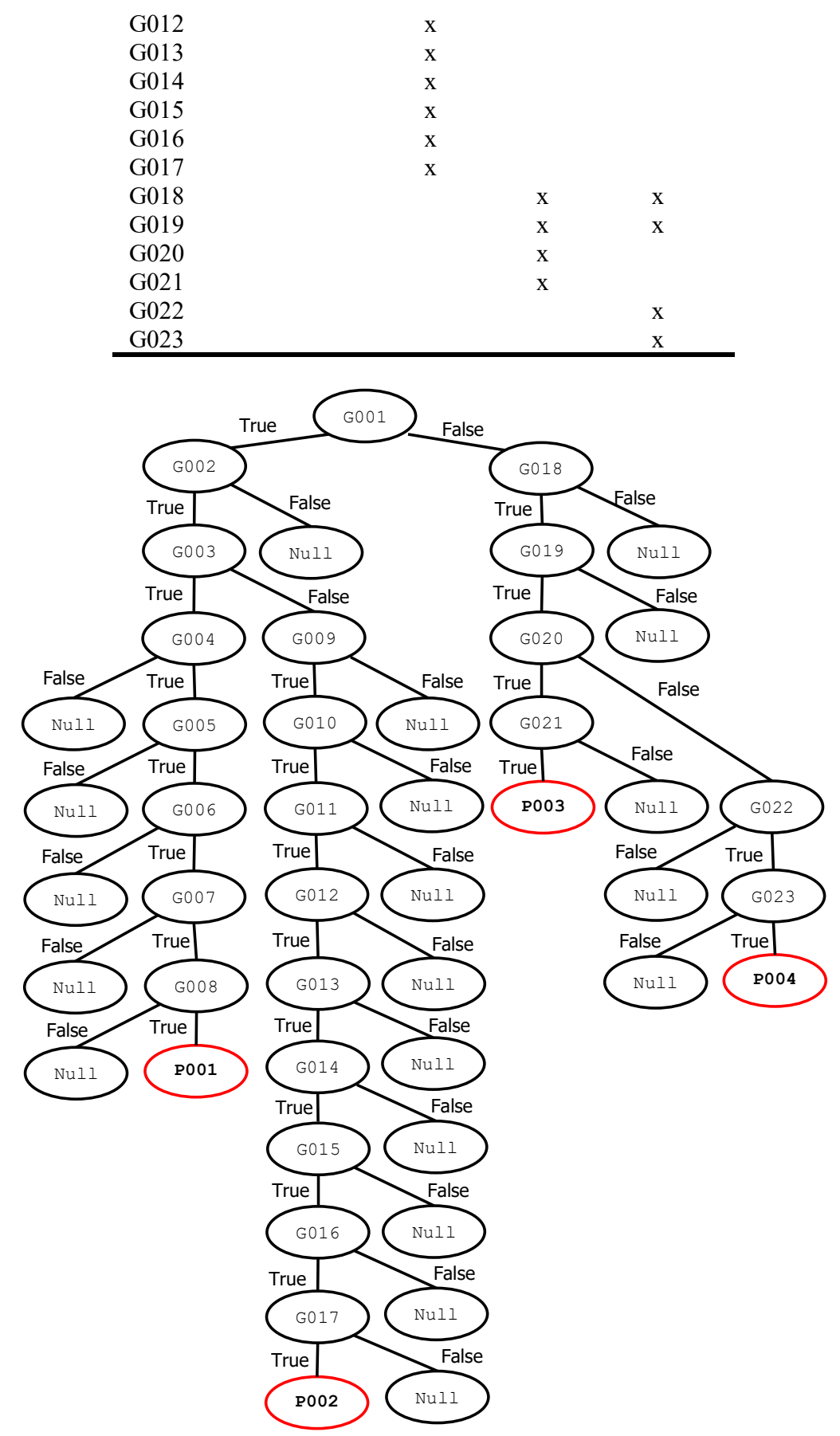

Fig. 4 Decision Tree structure for Children Mental Retardation Prediction 
Table. 5 Rule-based Representation for Children Mental Retardation Prediction

\begin{tabular}{|c|c|}
\hline Rule Number & Rule Description \\
\hline R001 & $\begin{array}{l}\text { IF G001 }=\text { TRUE, THEN IF G002 }=\text { TRUE, THEN IF G003 }=\text { TRUE, THEN } \\
\text { IF G004 }=\text { TRUE, THEN IF G005 }=\text { TRUE, THEN IF G006 }=\text { TRUE, THEN } \\
\text { IF G007 }=\text { TRUE, THEN IF G008 }=\text { TRUE, THEN P001 }\end{array}$ \\
\hline R002 & IF G001 = TRUE, THEN IF G002 = FALSE, THEN NULL \\
\hline R003 & $\begin{array}{l}\text { IF G001 = TRUE, THEN IF G002 = TRUE, THEN IF G003 = TRUE, THEN IF } \\
\text { G004 = FALSE, THEN NULL }\end{array}$ \\
\hline R004 & $\begin{array}{l}\text { IF G001 = TRUE, THEN IF G002 = TRUE, THEN IF G003 = TRUE, THEN IF } \\
\text { G004 = TRUE, THEN IF G005 = FALSE, THEN NULL }\end{array}$ \\
\hline R005 & $\begin{array}{l}\text { IF G001 = TRUE, THEN IF G002 = TRUE, THEN IF G003 = TRUE, THEN IF } \\
\text { G004 = TRUE, THEN IF G005 = TRUE, THEN IF G006 = FALSE, THEN NULL }\end{array}$ \\
\hline R006 & $\begin{array}{l}\text { IF G001 = TRUE, THEN IF G002 = TRUE, THEN IF G003 = TRUE, THEN IF } \\
\text { G004 = TRUE, THEN IF G005 = TRUE, THEN IF G006 = TRUE, THEN IF G007 } \\
=\text { FALSE, THEN NULL }\end{array}$ \\
\hline R007 & $\begin{array}{l}\text { IF G001 = TRUE, THEN IF G002 = TRUE, THEN IF G003 = TRUE, THEN IF } \\
\text { G004 = TRUE, THEN IF G005 = TRUE, THEN IF G006 = TRUE, THEN IF G007 } \\
=\text { TRUE, THEN IF G008 = FALSE, THEN NULL }\end{array}$ \\
\hline R008 & $\begin{array}{l}\text { IF G001 }=\text { TRUE, } \text { THEN IF G002 }=\text { TRUE, THEN IF G003 }=\text { FALSE, THEN } \\
\text { IF G009 }=\text { TRUE, THEN IF G010 }=\text { TRUE, THEN IF G011 }=\text { TRUE, THEN } \\
\text { IF G012 }=\text { TRUE, THEN IF G013 }=\text { TRUE, THEN IF G014 }=\text { TRUE, THEN } \\
\text { IF G015 }=\text { TRUE, THEN IF G016 }=\text { TRUE, THEN IF G017 }=\text { TRUE, THEN } \\
\text { P002 }\end{array}$ \\
\hline R009 & $\begin{array}{l}\text { IF G001 = TRUE, THEN IF G002 = TRUE, THEN IF G003 = FALSE, THEN IF } \\
\text { G009 = FALSE, THEN NULL }\end{array}$ \\
\hline R010 & $\begin{array}{l}\text { IF G001 = TRUE, THEN IF G002 = TRUE, THEN IF G003 = FALSE, THEN IF } \\
\text { G009 = TRUE, THEN IF G010 = FALSE, THEN TRUE }\end{array}$ \\
\hline R011 & $\begin{array}{l}\text { IF G001 = TRUE, THEN IF G002 = TRUE, THEN IF G003 = FALSE, THEN IF } \\
\text { G009 = TRUE, THEN IF G010 = TRUE, THEN IF G011 = FALSE, THEN NULL }\end{array}$ \\
\hline R012 & $\begin{array}{l}\text { IF G001 = TRUE, THEN IF G002 = TRUE, THEN IF G003 = FALSE, THEN IF } \\
\text { G009 = TRUE, THEN IF G010 = TRUE, THEN IF G011 = TRUE, THEN IF G012 } \\
=\text { FALSE, THEN NULL }\end{array}$ \\
\hline R013 & $\begin{array}{l}\text { IF G001 = TRUE, THEN IF G002 = TRUE, THEN IF G003 = FALSE, THEN IF } \\
\text { G009 = TRUE, THEN IF G010 = TRUE, THEN IF G011 = TRUE, THEN IF G012 } \\
=\text { TRUE, THEN IF G013 = FALSE, THEN NULL }\end{array}$ \\
\hline R014 & $\begin{array}{l}\text { IF G001 = TRUE, THEN IF G002 = TRUE, THEN IF G003 = FALSE, THEN IF } \\
\text { G009 = TRUE, THEN IF G010 = TRUE, THEN IF G011 = TRUE, THEN IF G012 } \\
=\text { TRUE, THEN IF G013 = TRUE, THEN IF G014 = FALSE, THEN NULL }\end{array}$ \\
\hline R015 & $\begin{array}{l}\text { IF G001 = TRUE, THEN IF G002 = TRUE, THEN IF G003 = FALSE, THEN IF } \\
\text { G009 = TRUE, THEN IF G010 = TRUE, THEN IF G011 = TRUE, THEN IF G012 } \\
=\text { TRUE, THEN IF G013 = TRUE, THEN IF G014 = TRUE, THEN IF G015 = } \\
\text { FALSE, THEN NULL }\end{array}$ \\
\hline R016 & $\begin{array}{l}\text { IF G001 = TRUE, THEN IF G002 = TRUE, THEN IF G003 = FALSE, THEN IF } \\
\text { G009 = TRUE, THEN IF G010 = TRUE, THEN IF G011 = TRUE, THEN IF G012 } \\
=\text { TRUE, THEN IF G013 = TRUE, THEN IF G014 = TRUE, THEN IF G015 = } \\
\text { TRUE, THEN IF G016 = FALSE, THEN NULL }\end{array}$ \\
\hline R017 & $\begin{array}{l}\text { IF G001 = TRUE, THEN IF G002 = TRUE, THEN IF G003 = FALSE, THEN IF } \\
\text { G009 = TRUE, THEN IF G010 = TRUE, THEN IF G011 = TRUE, THEN IF G012 } \\
=\text { TRUE, THEN IF G013 = TRUE, THEN IF G014 = TRUE, THEN IF G015 = } \\
\text { TRUE, THEN IF G016 = TRUE, THEN IF G017 = FALSE, THEN NULL }\end{array}$ \\
\hline R018 & $\begin{array}{l}\text { IF G001 }=\text { FALSE, THEN IF G018 }=\text { TRUE, THEN IF G019 }=\text { TRUE, THEN } \\
\text { IF G020 }=\text { TRUE, THEN IF G021 }=\text { TRUE, THEN P003 }\end{array}$ \\
\hline
\end{tabular}




\begin{tabular}{ll}
\hline Rule Number & Rule Description \\
\hline R019 & IF G001 = FALSE, THEN IF G018 = FALSE, THEN NULL \\
R020 & IF G001 = FALSE, THEN IF G018 = TRUE, THEN IF G019 = FALSE, THEN \\
& NULL \\
R021 & IF G001 = FALSE, THEN IF G018 = TRUE, THEN IF G019 = TRUE, THEN \\
& IF G020 = FALSE, THEN IF G022 = TRUE, THEN IF G023 = TRUE, THEN \\
& P004 \\
R022 & IF G001 = FALSE, THEN IF G018 = TRUE, THEN IF G019 = TRUE, THEN IF \\
& G020 = TRUE, THEN IF G021 = FALSE, THEN NULL \\
R023 & IF G001 = FALSE, THEN IF G018 = TRUE, THEN IF G019 = TRUE, THEN IF \\
& G020 = FALSE, THEN IF G022 = FALSE, THEN NULL \\
R024 & IF G001 = FALSE, THEN IF G018 = TRUE, THEN IF G019 = TRUE, THEN IF \\
& G020 = FALSE, THEN IF G022 = TRUE, THEN IF G023 = FALSE, THEN \\
& NULL \\
\hline
\end{tabular}

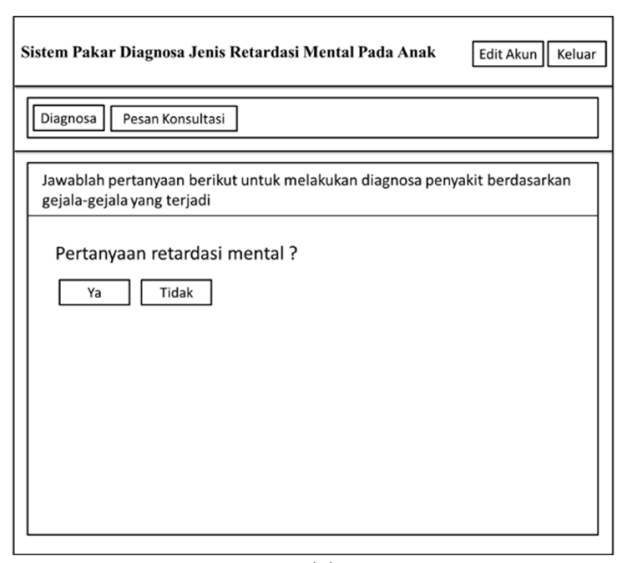

(a)

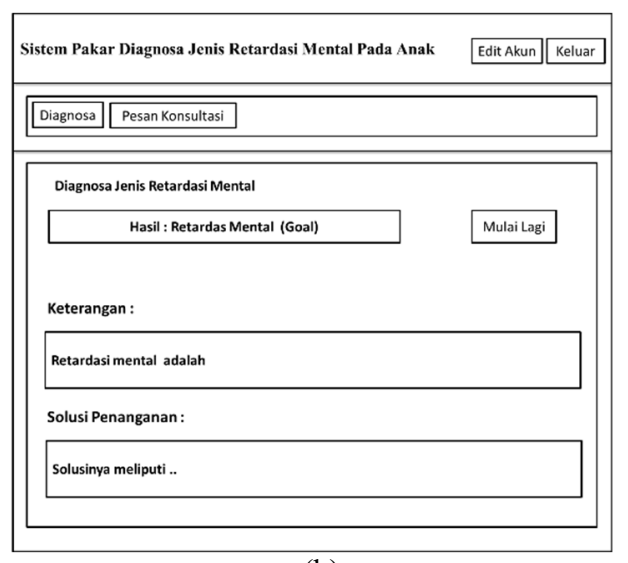

(b)

Fig. 5 (a) The example of User Interface Design for Answer the Symptoms Diagnosis, (b) The example of User Interface Design for Children Mental Retardation Prediction Result

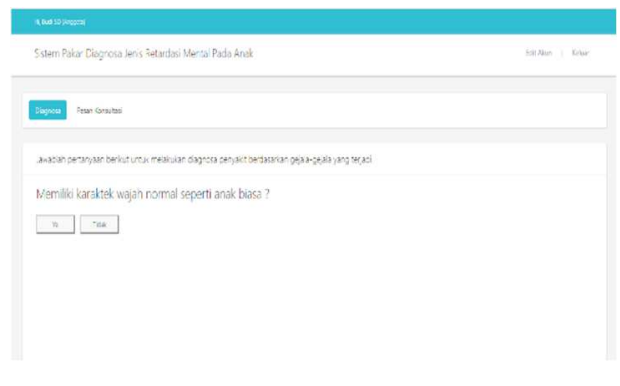

(a)

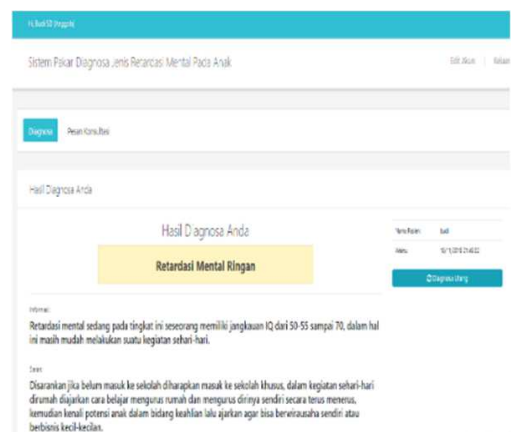

(b)

Fig. 6 (a) The example of User Interface Implementation for Answer the Symptoms Diagnosis, (b) The example of User Interface Implementation for Children Mental Retardation Prediction Result 


\subsection{Design Result}

In the design phase, ES for predicting children mental retardation is modeled using Unified Modeling Languange (UML) that based on object oriented analysis and design [37]-[39]. Besides using Use Case Diagram and its Use Case scenario, the system also design using Activity Diagram, Sequence Diagram, and Class Diagram. In this phase also design the data model and user interface that is described the example in the Figure 5 (present with Indoensian language).

\subsection{Implementation Result}

Implementation phase build the system using PHP programming language with MySQL as database. All of rules from Table 5 are implemented in the program code and tree structure as data structure that is design in accordance with Figure 4. The user interface design is also implemented such as show in Figure 6 as an example.

\subsection{Testing Result}

On the testing, it is done the trial system using blackbox testing that is one of the testing software focused on the functionality side, especially on the input and output application. From the blackbox testing result in the Table 6 shows that all of the function if the system are run correctly. Then, from the evaluation process using questionnaire with 8 respondents and 7 question in accordance with usability of the system show that the system is usable and easy to use. The results of quetionnaire are shown in the Figure 7. Because of FC is a rule-based algorithm, as long as the rules are complete and appropriate, the prediction results will be appropriate. In this system the FC algorithm has stored all the rules to predict children mental retardation completely.

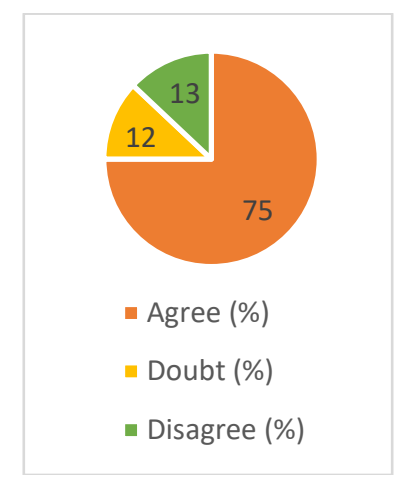

(a)

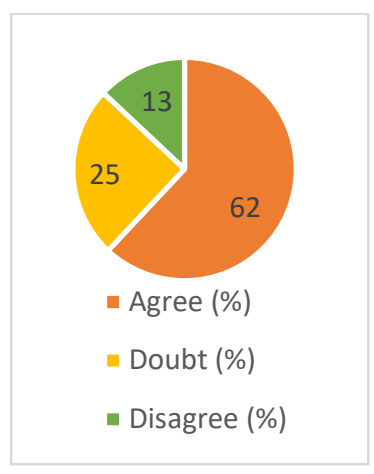

(b)

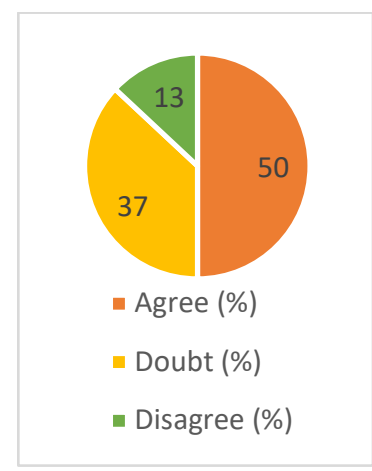

(c) 


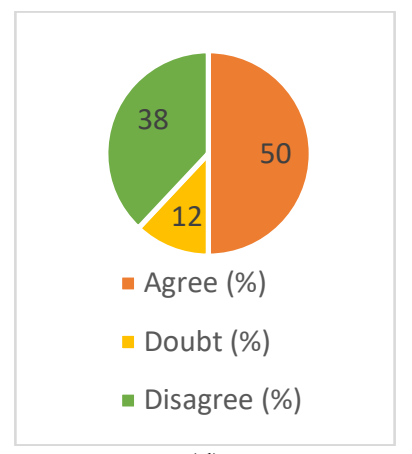

(d) (a) Easy to use and useful

(b) Undarstandable and reach expected function

(c) In accordance with the needs

(d) Fast enough in resulting the prediction

(e) Comfortable

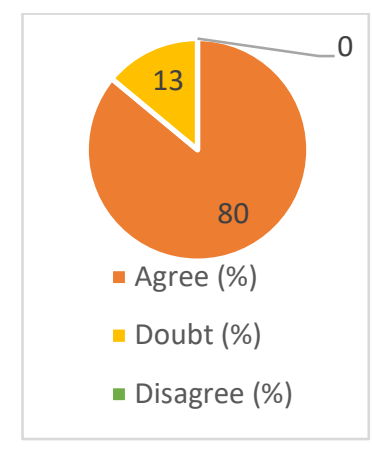

(e)

Fig. 7 The Result of System Evaluation using Questionnaire

Table. 6 Blackbox Testing Result

\begin{tabular}{|c|c|c|c|}
\hline Tested Items & Description & Match with Expected Output & Result \\
\hline $\begin{array}{l}\text { Registration } \\
\text { Feature }\end{array}$ & $\begin{array}{l}\text { Users can fill in their } \\
\text { data into system and } \\
\text { system store the data. }\end{array}$ & Yes & Success \\
\hline Login & $\begin{array}{l}\text { Users can Login into the } \\
\text { system if their account is } \\
\text { valid, if not valid the } \\
\text { system will be informed } \\
\text { the error message. }\end{array}$ & Yes & Success \\
\hline $\begin{array}{l}\text { Manage } \\
\text { symptoms }\end{array}$ & $\begin{array}{l}\text { User (administrator) } \\
\text { prepare the symptoms } \\
\text { and the question in the } \\
\text { ES for diagnose the } \\
\text { children mental } \\
\text { retardation from patient }\end{array}$ & Yes & Success \\
\hline $\begin{array}{l}\text { Manage type } \\
\text { of mental } \\
\text { retardation }\end{array}$ & $\begin{array}{l}\text { User (administrator) set } \\
\text { the type of children } \\
\text { mental retardation, and } \\
\text { the setting must be saved } \\
\text { well }\end{array}$ & Yes & Success \\
\hline $\begin{array}{l}\text { Symptoms } \\
\text { form }\end{array}$ & $\begin{array}{l}\text { System provide the form } \\
\text { for patient answer the } \\
\text { symptoms and ES will } \\
\text { be diagnosed basedaon } \\
\text { the input. All of the } \\
\text { input will be stored in } \\
\text { the system }\end{array}$ & Yes & Success \\
\hline $\begin{array}{l}\text { Run } \\
\text { Prediction }\end{array}$ & $\begin{array}{l}\text { Forward Chaining will } \\
\text { be run the rules or } \\
\text { knowledge of the expert. }\end{array}$ & Yes & Success \\
\hline $\begin{array}{l}\text { Show the } \\
\text { result }\end{array}$ & $\begin{array}{l}\text { System show the result } \\
\text { of children mental } \\
\text { retardation prediction, } \\
\text { and the information } \\
\text { about the treatment. }\end{array}$ & Yes & Success \\
\hline
\end{tabular}




\section{Conclusions}

Children mental retardation is a serious case because can impact the affect the development and future of the child. This research contribute for prediction the symptoms of children mental retardation utilizing Expert System technology with Forward Chaining algorithm early. Based on the expertiment result, Forward Chaining algorithm had been implemented well because of all of the rules was defined completely to predict the result. And also the functionality and usability of the system are good in accordance with the result of the blackbox testing and evaluation using questionnaire.

\section{References}

[1] D. J. Fidler and L. Nadel, "Education and children with down syndrome: Neuroscience, development, and intervention," Mental Retardation and Developmental Disabilities Research Reviews. 2007.

[2] U. Dave and D. Shetty, "Chromosomal Abnormalities in Mental Retardation," Indian J. Hum. Genet., vol. 10 , no. $1-3$, pp. $21-32,2010$.

[3] J. Giarrantano and G. Relay, Expert System: Principle and Programming. Bouston, 2004.

[4] J. P. S. Situmeang, H. Bidjuni, and J. Lolong, "HUBUNGAN STATUS SOSIO DEMOGRAFI DAN STATUS AKADEMIK ANAK DENGAN KEMANDIRIAN ANAK RETARDASI MENTAL DI SLB YAYASAN PEMBINAAN ANAK CACAT MANADO," e-journal Keperawatan (e-Kp), 2016.

[5] Badan Pusat Statistik, "Proyeksi penduduk indonesia 2010-2035," 2013.

[6] S. Russel and P. Norvig, Artificial intelligence — a modern approach 3rd Edition. 2012.

[7] M. NEGNEVITSKY, Artificial Intelligence: A Guide to Intelligent Systems. 2017.

[8] S. HN, "Perkembangan Revolusi Industri 4.0 (Industrial Revolution 4.0) dan Tantangan ke Depan," Belajar Ekonomi, 2018. [Online]. Available: https://www.ajarekonomi.com/2018/05/perkembanganrevolusi-industri-40.html. [Accessed: 08-Jun-2019].

[9] P. Hamet and J. Tremblay, “Artificial intelligence in medicine,” Metabolism., 2017.

[10] I. Yunanto, A. A., Herumurti, D., \& Kuswardayan, "Kecerdasan Buatan Pada Game Edukasi Untuk Pembelajaran Bahasa Inggris Berbasis Pendekatan Heuristik Similaritas," J. Sist. dan Inform., 2017.

[11] A. Dadiesh and J. Gilbert, "Strategic Management Process," Hum. Resour. Manage., 2001.

[12] M. Abdi, D. Herumurti, and I. Kuswardayan, "Analisis Perbandingan Kecerdasan Buatan pada Computer Player dalam Mengambil Keputusan pada Game Battle RPG,” JUTI J. Ilm. Teknol. Inf., 2017.

[13] H. K. W. Silvia Rostianingsih, Gregorius Satia Budhi, "GAME SIMULASI FINITE STATE MACHINE UNTUK PERTANIAN DAN PETERNAKAN,” Sci. reposity J., 2017.

[14] Y. A. Gerhana, W. B. Zulfikar, A. H. Ramdani, and M. A. Ramdhani, "Implementation of Nearest Neighbor using HSV to Identify Skin Disease," IOP Conf. Ser. Mater. Sci. Eng., vol. 288, no. 1, p. 012153 1234567890 Implementation, 2018.

[15] H. Sulastri and A. I. Gufroni, "Penerapan Data Mining dalam Pengelompokan Penderita Thalassaemia," Teknol. dan Sist. Inf., vol. 03, no. 02, pp. 299-305, 2017.

[16] K. R. Pradeep and N. C. Naveen, "Lung Cancer Survivability Prediction based on Performance Using Classification Techniques of Support Vector Machines, C4. 5 and Naive Bayes Algorithms for Healthcare Analytics," Procedia Comput. Sci., vol. 132, pp. 412-420, 2018.

[17] M. Agarwal and S. Goel, "Expert system and it's requirement engineering process," Int. Conf. Recent Adv. Innov. Eng., pp. 1-4, 2014.

[18] D. S. Maylawati, M. A. Ramdhani, W. B. Zulfikar, I. Taufik, and W. Darmalaksana, "Expert system for predicting the early pregnancy with disorders using artificial neural network," in 20175 th International Conference on Cyber and IT Service Management, CITSM 2017, 2017.

[19] N. I. Kurniati, H. Mubarok, and A. Reinaldi, "Rancang Bangun Sistem Pakar Diagnosa tingkat Depresi Pada Mahasiswa Tingkat Akhir Menggunakan Metode Fuzzy Tsukamoto(Studi Kasus: 
Universitas Siliwangi)," J. Online Inform., vol. 2, no. 1, p. 49, 2017.

[20] G. P. K. Asnawati, Yupianti, "Sistem Pakar Untuk Mengidentifikasi Penyakit Ikan Lele Menggunkan Metode Backward Chaining," J. Media Infotama, vol. 9, no. 1, 2013.

[21] S. Khosyi'Ah, M. Irfan, D. S. Maylawati, and O. S. Mukhlas, "Analysis of Rules for Islamic Inheritance Law in Indonesia Using Hybrid Rule Based Learning," in IOP Conference Series: Materials Science and Engineering, 2018.

[22] L. Perdana, D. Nugroho, and Kustanto, "Sistem Pakar Untuk Diagnosis Penyakit Ginjal Dengan Metode Forward Chaining," J. TIKomSiN, 2013.

[23] D. Novaliendry, C. H. Yang, and A. Y. Denno Guara Labukti, "The expert system application for diagnosing human vitamin deficiency through forward chaining method," Int. Conf. ICT Converg. 2015 Innov. Towar. IoT, 5G, Smart Media Era, ICTC 2015, pp. 53-58, 2015.

[24] A. Al-Ajlan, "The Comparison between Forward and Backward Chaining," Int. J. Mach. Learn. Comput., 2015.

[25] Ahmad Al Kaafi, "Sistem Pakar Diagnosa Autis Pada Anak Dengan Menggunakan Metode Forward Chaining," Speed - Sentra Penelit. Eng. dan Edukasi, 2017.

[26] I. Astuti and H. Sutarno, "The Expert System of Children's Digestive Tract Diseases Diagnostic using Combination of Forward Chaining and Certainty Factor Methods," Int. Conf. Sci. Inf. Technol., pp. 608-612, 2017.

[27] I. Sommerville, Software Engineering. 2010.

[28] R. S. Pressman, Software Engineering: A Practitioner's Approach, 7th ed. New York: McGraw-Hill, 2011.

[29] M. A. Ramdhani, D. Sa'adillah Maylawati, A. S. Amin, and H. Aulawi, "Requirements Elicitation in Software Engineering," Int. J. Eng. Technol., 2018.

[30] I. Akil, "Analisa Efektifitas Metode Forward Chaining Dan Backward Chaining," J. Pilar Nusa Mandiri, 2017.

[31] J. Ouwuzuruigbo, "Forward Chaining and Backward Chaining system in Artificial Intelligent," Slideshare, $2017 . \quad$ [Online]. Available: https://www.slideshare.net/leonardonwuzuruigbo/forwardchaining-\%0Aand-backward-chainingsystems-in-artificial-inteligence-55781240. [Accessed: 15-Apr-2017].

[32]Anonymous, "Forward and Backward Chaining." [Online]. Available: http://www.iiia.csic.es/ puyol/IAGA/Teoria/07-AgentsLogicsII.pdf. [Accessed: 15-Apr-2017].

[33] A. ALFIARINI, N. MULYANA, and I. ISHARTONO, "MODAL SOSIAL DALAM PENANGANAN PENDERItA RETARDASI MENTAL," Pros. Penelit. dan Pengabdi. Kpd. Masy., 2017.

[34] R. D. S. W Eva Diah; AT, Putu Oky, "Identifikasi Penyebab Retardasi Mental Siswa SLB Melalui Analisis Sitogenetik dan PCR," J. Kedokt. Brawijaya, 2016.

[35] S. Fithriya and S. Lestari, "Peningkatan Interaksi Ibu dan Anak Retardasi Mental melalui Pelatihan Bermain Pura-Pura," J. Psikol., 2016.

[36] R. Ramayumi, A. E. Nurdin, and S. Nurhajjah, "KARAKTERISTIK PENDERITA RETARDASI MENTAL DI SLB KOTA BUKITTINGGI," Maj. Kedokt. Andalas, 2015.

[37] G. Booch, Object-Oriented Analysis and Design, 2nd ed. Santa Clara, California: Addison-Wesley, 1998.

[38] P. Coad and E. Yourdon, “Object Oriented Analysis,” Comput. Aided Archit. Des., 1991.

[39] P. Coad and E. Yourdon, Object-Oriented Design, 1st ed. Yourdon Computing Press Series, 1990. 